REVISTA X, Curitiba, volume 14, n.6,p. 107-127, 2019.

\title{
“ANY IDEA FOR A WARM-UP?", WHEN REQUESTS FOR HELP LEAD TO TEACHER PROFESSIONAL DEVELOPMENT
}

“Alguma ideia para um warm-up?”, quando pedidos de ajuda conduzem à formação de professores

\author{
William KIRSCH (UFCSPA) ${ }^{1}$
}

\begin{abstract}
This paper discusses teacher-room interaction in a community of practice (WENGER, 1998) of student teachers of English as an Additional Language, focusing on the dyad requests for help - offers of help, which often take place in the community. The community was affiliated with the extinct Languages without Borders in a large university in the south of Brazil. The research aligns with the paradigm of practice theory (YOUNG, 2009) and uses qualitative and interpretive methodology (ERICKSON, 1990; MASON, 2002). It is possible to conclude that the kind of teacher-room interaction presented in this paper contributes to student teachers' professional development throughout their trajectory in the community.
\end{abstract}

KEYWORDS: Languages without Borders; Teacher Development; Asking for help.

RESUMO: Este artigo discute a interação em sala de professores em uma comunidade de prática de professores de inglês como língua adicional em formação, focando na díade pedidos de ajuda - oferta de ajuda, frequentes naquela comunidade. A comunidade estava vinculada ao extinto Programa Idiomas sem Fronteiras em uma grande universidade do sul do Brasil. A pesquisa alinha-se com a abordagem proposta pela teoria da prática (YOUNG, 2009) e, metodologicamente, com a tradição qualitativa e interpretativa de investigação (ERICKSON, 1990; MASON, 2002). É possível concluir que este tipo de interação de sala de professores tenha contribuído para a formação de professores através de sua trajetória nesta comunidade.

PALAVRAS-CHAVE: Idiomas sem Fronteiras; Formação de Professores; Interação de sala dos professores.

\section{INTRODUCTION}

When we think of teacher education, teacher training or teacher development ${ }^{2}$, what usually comes to our minds are somehow structured and formal practices, such as attending classes, lectures and workshops; participating in seminars, discussions, roundtables or brown bags; or, still, reading professional publications in journals, books

\footnotetext{
${ }^{1}$ Professor Adjunto de Língua Inglesa na Universidade Federal de Ciências da Saúde de Porto Alegre (UFCSPA) e Doutor em Linguística Aplicada pela Universidade Federal do Rio Grande do Sul (UFRGS). william_kirsch@yahoo.com.br

${ }^{2}$ I will stick with teacher development for reasons delineated in the second section.
} 
REVISTA X, Curitiba, volume 14, n.6,p. 107-127, 2019.

and magazines. Nevertheless, a relevant part of our development as teachers happens through participating in professional communities and interacting with people with whom we share our goals, problems and ways of doing things. Therefore, a comprehensive notion of teacher development should encompass unstructured practices like talking shop in teachers' rooms, telling classrooms stories and preparing lessons together. However, teacher development research has often overlooked said informal and unstructured practices. Therefore, we lack research work grounded on empiric fieldwork looking into such practices in their most likely environment - communities where teachers do their work.

In this article, I discuss the role of teacher-room interaction in the development of teachers of English as an Additional Language (EAL), focusing specifically on the requests for help that participants often direct at each other when they face difficulties in their teaching practices, as well as the offers of help that often stem from such requests $^{3}$.The central persuasion here is that such interactions foster professional development for the student teachers who partake in the community.

The article is part of a research project that investigated the professional development of undergraduate student teachers of EAL in a Community of Practice $(\mathrm{CoP})^{4}$ generated by a program named Languages without Borders $(\mathrm{LwB})^{5}$ at a large university in the south of Brazil. The purpose of the research was to observe, describe, analyze and elucidate the practices that foster professional development for the student teachers engaged in this community. The present study is affiliated with the paradigm of Practice Theory (YOUNG, 2009; 2010) and, consequently, embraces CoP (Wenger, 1998; 2010) as an approach to learning; methodologically, it relies on qualitative (ERICKSON, 1990; MASON, 2002) methods of data generation and analysis, and on interactional sociolinguistics (TANNEN, 1993; GUMPERZ, 2002).

\footnotetext{
${ }^{3}$ Requesting for help is when one participant directs a turn-in-interaction at (an)other participant(s) indexing that he or she cannot do something alone (GARCEZ AND SALIMEN, 2011, p. 9). In the subsequent turn, the addressee(s) of the request may or may not offer the help requested, although offering help is the preferred response.

${ }^{4}$ Also explained in section 2.

${ }^{5} \mathrm{LwB}$ is a program focused on improving additional language proficiency in public universities in Brazil. Universities opened language centers, consisting of a coordination (professors from English departments) and student teachers (usually undergrad or grad students). The student teachers are responsible for teaching additional language, mainly English, classes for university community (faculty, students and staff), and partake in pedagogical meetings.
} 
REVISTA X, Curitiba, volume 14, n.6,p. 107-127, 2019.

The article is divided in the following parts: this introduction; a review of literature; a review of the methodology used for the study; a presentation of the data; and a discussion followed by concluding remarks.

\section{THEORETICAL FRAMEWORK}

In this section, I will discuss the central elements in this investigation by reviewing previous work that over which this investigation stands. I will address teacher development in the specific ways pursued here; Practice Theory and the CoP approach to learning; and a tentative synthesis of the analytic concepts to do research within this paradigm.

\section{Teacher development}

Over the past few years, the discussions concerning education enhancement have focused on teachers - especially their initial education and continued development (NÓVOA 1995;VILLEGAS-REIMERS, 2003; OCDE, 2006; MONGE AND GOMÉZ, 2018). This happened after such discussion spent years focusing on technocratic issues, such as school management and teaching methodologies (NÓVOA, 2009). Concentrating on teachers and their education rather than on technocratic issues is a shift of paradigm that has been welcomed by education researchers and teacher educators, for it pursues a needed 'appreciation of teachers' work and promotes the concept of teaching as a profession" (VILLEGAS-REIMERS, 2003, 7, emphasis in original). Thus, in the present paper I understand professional development as a "lifelong process which begins with the initial preparation that teachers receive (whether at an institute of teacher education or actually on the job) and continues until retirement" (VILLEGAS-REIMERS, 2003, 8). Therefore, teachers are in development through their entire career.

Several teacher educators and researchers have called for a change in teacher development paradigms. Antonio Nóvoa (1992) proposes an approach that shifts focus from "a perspective that is excessively centered on academic dimensions (areas, curricula, courses, etc.) to one that is centered on the professional domain (p. 1)"6. After discussing teacher education and the teachers' career over the twentieth century in Portugal, the author claims for a more clinical teacher education - one that is based on

\footnotetext{
${ }^{6}$ [...] perspectiva excessivamente centrada nas dimensões acadêmicas (áreas, currículos, disciplinas, etc.) para uma perspectiva centrada no terreno profissional.
} 
the articulation of practice and reflection about practice -, and for a more investigative teacher education - one that confronts teachers with the production of original knowledge. Nóvoa (2007) claims that there is an important paradox in the debate on teacher education; on the one hand, there is a cohesive and well-connected network of convergent discourses in the field of teacher education, while, on the other hand, there is a lack of quality practices and empirical experiences to show that such discourses are being converted into policy and practice. The author presents three antidotes for resolving such paradox: (1) bringing teacher education to "the inside" of the teaching profession; (2) promoting new models of organization of the profession; (3) reinforcing personal and public image of teachers in communities.

Professional development, therefore, includes formal practices (such as attending workshops, lectures and professional seminars, etc.) and informal ones (reading professional publications, watching television documentaries related to an academic discipline, etc.) practices. Consequently, researching professional development involves looking into the experiences and processes by which it occurs and the contexts where it takes place (GASNER, 2000). For this reason, empirically grounded research work is paramount for looking into the processes (social, political, affective) involved in teacher development in order to shed light on how it happens in the contexts where it happens.

This investigation has focused on the development of EAL teachers. For this reason, I will review research that has focused on teacher development in CoPs of additional language teachers from a qualitative scope. Merrill (2016) investigated the additional language teacher assistants (TAs) of a big and reputable public university in Midwestern U.S. and focused on elucidating the aspects that help CoPs form and thrive. In a mix-methods study, the author conducted a survey with TAs of additional languages and, after that, interviewed focal participants. She claims that the opportunity to interact in both public and private spaces is one of the chief characteristics of successful CoPs. In addition, she found that engagement in a wide array of communities' interactions- such as department events, planning classes and writing evaluations together - helped them develop professionally.

Costa (2013) researched the teacher professional development practices in a CoP of teachers of Portuguese as an additional language. Based on the work of Portuguese educator Nóvoa (1995), social scientist Schön (1987) and literacy theorists (HEATH, 
1982; HEATH AND STREET, 2008), the author proposed the concepts of "teacher development event" and "teacher development practice"7. The research setting was a Brazilian Center in a Latin American country, where teachers from a variety of academic backgrounds teach Portuguese. His ethnographic work aimed at describing and analyzing the interactional events in which participants align to professional development activities, or, teacher development events. A teacher development event consists of an interactional event whose goal is either explicit professional learning or the resolution of a pedagogical problem made relevant by the participants - such as ways to explain a grammar rule, organize a pedagogical task or design an evaluation instrument, and can be based on the sharing of material, stories and experiences (COSTA, 2013, p. 76). He then uses this concept as an analytical unit to understand how teachers learn to be teachers by interacting with one another. In this sense, according to the author, an analyst elucidates the interactional events in which participants are aligned to professional development in order to, by attending to their recurrent aspects, understand how these events comprise more abstract and generic landscapes - the practices. This view, as I will delineate in the next section, is compatible with the traditions of Practice Theory and with the $\mathrm{CoP}$ approach to learning.

\section{Practice Theory and Communities of Practice}

In this section, I will define what I understand as Practice Theory as well as conceptualize the idea of CoPs as places of learning. Then, I will focus on how these concepts were used to construct the methodology for the present study.

Practice Theory is a reference to the use of the terms practice, practices, or praxis that denotes a concept developed during the 1970s to refer to human actions that are both the medium through which social structure is enacted as well as the outcome of that structure. Young (2009) uses the term practice as performance in context, understood as the "network of physical, spatial, temporal, social, interactional, institutional, political, and historical circumstances in which participants do a practice" (p.3). Thus, it involves attention to (1) a focal event; and (2) a field of action within which that event is embedded" (GOODWIN ANDDURANTI, 1992, p. 3).

\footnotetext{
${ }^{7}$ In Portuguese, respectively evento de formação de professores and prática de formação de professores. The event is the social, here-and-now interaction, whereas the practice has a more abstract, mediating function. I will address this down the road.
} 
REVISTA X, Curitiba, volume 14, n.6,p. 107-127, 2019.

Analyzing practices involves paying attention not only to the "production of meanings by participants as they employ in local actions the verbal, nonverbal, and interactional resources that they command" (YOUNG, 2009, p.2) but also to how employment of such resources reflects and creates the processes and meanings of the community in which the local action occurs. In other words, to analyze practices one has to attend to people doing things with one another at a given time-place (interactional events) as well as consider that the recurrence of such events creates history in a given community (workshops, lectures, seminars, brown-bags, microteaching, and roundtables are well known examples in academia). This analytic endeavor, therefore, calls for observing, describing and analyzing events in order to be able to construct an understanding of how such events enter CoP landscape as "folk models" for future action as well as a repertoire to understand past action ${ }^{8}$. For this reason, we observe what is concrete in order to understand what underlies it.

The idea of CoPs as places of learning comes from the work of Lave and Wenger (LAVE AND WENGER, 1991; WENGER, 1998). CoPs consist of "groups of people who share a concern or passion for something they do and learn how to do it better as they interact regularly" (WENGER, n.d.). CoPs are often defined by three key elements: (1) a shared domain of interest; (2) a defined community; (3) a shared repertory of practices. For a CoP approach, learning is the production of social structure through two (inter/co)related processes: participation and reification. Participation consists of how members "engage in emergent structure, complex relationships, selforganization, dynamic boundaries, ongoing negotiation of identity and cultural meaning, to mention a few", while reification consists of how our engagements "produce physical and conceptual artifacts-words, tools, concepts, methods, stories, documents, links to resources" (p. 1). Learning, in this paradigm, is equivalent to the production of identities that (1) are aligned ${ }^{9}$ to community's goals, values and ways of doing things, and (2) have repertories that enables them to participate in CoP's practices proficiently. In other words, learning is becoming a full participant - someone with solid proficiency of CoPs' ways of doing things, meanings, ways of speaking, stories, etc.

Methodologically, this entails that the analyst looks into both participation and reification, using the idea of practice as a bridge between both lines of inquiry. In other

\footnotetext{
${ }^{8}$ The similarity to Bakhtin (1981)'s concept of speech genre is by no means a coincidence.

${ }^{9}$ Alignment does not mean obedience, as disobedience may itself produce new forms of alignment.
} 
words, the concept of practice may help connect local action with the history produced by the ecology of such local actions over time and space in a CoP. This is the reason why I am proposing to look into how the requests for help may enhance professional development in two related layers: (1) attending to the interactional events recorded and transcribed in which participants are aligned to requesting and offering help; (2) attending to the generic aspects that connect such events as collection of related episodes. This is the way the analyst can move from event (here-and-now interactions) to practice (a generic and historical device construed by communities to make sense of their everyday business). It is also how one can look at practice in a contextual rather than reified manner.

\section{METHODS: RESEARCH SETTING, PARTICIPANTS, DATA GENERATION AND ANALYSIS}

The university researched is among the largest and best-ranked institutions of upper education in Brazil. There, the Languages without Borders Center is located at the Department of Foreign Languages. At the time of the data generation, the members of the community consisted of:

- 3 Professors from the English Department (Ph.D.)

- 3 Fulbright English Teaching Assistants (recently graduated from US universities)

- 15 undergraduate student teachers (sophomore to senior year of teacher certification on EAL or joint degree EAL and Portuguese and Literature)

- 1 graduate student teacher

- 1 master researcher who is herself a former student teacher

- 2 former undergraduate student teachers

Below I present a list of all research participants that appear in the data presented in this article. All proper names presented henceforth are pseudonyms.

\begin{tabular}{|l|l|l|}
\hline Pseudonym & Position & Education \\
\hline Maria Estevam & Pedagogical coordinator & Ph.D. \\
\hline Adam & Student teacher & Third year ${ }^{10}$ college \\
\hline Adriana & Student teacher & Second year college \\
\hline Lucas & Student teacher & First yearcollege \\
\hline
\end{tabular}

\footnotetext{
${ }^{10}$ At this teaching program, the English-Portuguese major is nine semesters long (four and a half years) and the English major is eight semesters long (four years).
} 
REVISTA X, Curitiba, volume 14, n.6,p. 107-127, 2019.

\begin{tabular}{|l|l|l|}
\hline Antonio & Former student teacher & Third year college \\
\hline Grazi & Student teacher & Third year college \\
\hline Antonia & Student teacher & Third year college \\
\hline Josiane & Student teacher & Senior year college \\
\hline Nadia & Student teacher & Senior year college \\
\hline Mariana & Student teacher & Senior year college \\
\hline Pedro & Student teacher & Senior year college \\
\hline
\end{tabular}

Table 1: Participants

Data was generated through field notes, photographs, artifact collection and audio recording (ERICKSON, 1990; MASON, 2002). I spent about three months doing fieldwork every other day for about four hours each time; after each field visit, about the same time was spent writing the full note and organizing materials. After observation, I conducted semi-structured interviews with five focal participants; the interviews were conversations with a purpose (MASON, 2002) and aimed at discussing participants' overall experience in the program rather than answering questions ${ }^{11}$.

The research questions that guided the investigation were the following:

- What practices contribute to the student teachers' professional development?

$\checkmark$ Where do they happen?

$\checkmark$ When do they happen?

$\checkmark$ Who are the participants?

- What activities (structured routines and pathways that facilitate or regulate actions; rules of appropriacy and eligibility - who does/doesn't, can/can't engage in particular activities) are integral to these practices ${ }^{12}$ ?

All the data was organized in a database on MaxQda $12^{13}$. Finally, the audio files were transcribed orthographically and coded (SALDAÑA, 2009) multiple times in order to elucidate that practices that seemed to foster teacher development for CoP members. Finally, after working on the emerging codes multiple times (reading,

\footnotetext{
${ }^{11}$ The interviewees were chosen according to the following criteria: (a) participation in teacher room interaction and pedagogical meetings; (b) rapport with me; (c) a mix of different time brackets in the program. I interviewedtwo long-timers (about two years of participation in the program; two novices (less than a year); and two in the middle (about a year).

${ }_{12}$ This question was adapted from Hamilton (1998).

${ }^{13}$ Available: https://www.maxqda.com (Last Visited: 23 jul. 2019).
} 
REVISTA X, Curitiba, volume 14, n.6,p. 107-127, 2019.

rereading, putting codes together, separating categories, etc.), the analysis reached its saturation point.

In the next session, I describe the moments in which participants are aligned to requesting/offering help to one another.

\section{RESULTS}

In this community, there was a room divided into a small reception and a larger room (no larger than 25 square meters) with two desktop computers, two couches, a round table and two large bookshelves, among other small things; this larger room was often referred to by participants as "the teachers' room". The teachers' room was a space for student teachers to prepare classes, grade homework, use desktop computers to access the internet, print materials, access the center's mini-library on EAL books (mostly, but not only, course books) or simply hang out together. Participants spent a lot time there - people started arriving at about 08am and the last people left when the building closed at 06pm. Participants came and went depending on their class times, taking turns, so the room was hardly ever crowded; some did not show up much, while some showed up every day. In this room, participants engaged in a number of interactions that revolved around their teaching practice - telling stories, preparing lessons together, writing evaluation together, grading papers, sharing materials, among others. The dyad asking for/offering help was one of them.

In this paper, I will present two segments that are typical of all the events categorized as request for help. Both took place in the teachers' room and emerged from everyday life in the community, without having been planned by the coordination of the program. After presenting and discussing the data, I will present a synoptic chart that summarizes all the interactional events themed in this category.

In the first segment, Adam, Lucas and Grazi are talking in the teachers' room while they prepare classes; Antonio is using the computer and singing. Adam was about 27 years old when the data was generated in a group where most were in their early 20 's. In addition to that, he had been a teacher at private language institutes for about 6 years total in a group where many people are starting to teach. He had dropped out of Law School and a Marketing School before choosing to study to be an English teacher. $\mathrm{He}$ is perceived in the community as a reference, especially by those who are just beginning to teach. In the field diary, we see that novices oftentimes reach out to him for help. Lucas, on the other hand, is inexperienced and in his first year in college. 
Antonio -former student teacher in the program who spends a lot of time in the teachers' room and attends teachers' meetings quite often. Adam is using the other computer while Lucas is sitting at the table and looking at a course book. The researcher is sitting on the couch, watching the scene. The conversation revolves around Antonio's singing - he is always singing. Some people start singing outside the building and Adam says, almost in a complaining key, "it's a lot of singing" in the room. From this moment on, the request for help unfolds. Let us look at it below ${ }^{14}$.

Excerpt 1: "It's a lot of singing"15

Adam: Pois é, né gente, é muita cantoria

Lucas: Ô, esses reviews tem que fazer todos com os alunos?

Adam: Quais reviews?

Lucas: As que tem no American English File

Adam: Olha só, o que eu faço: o review eu dou pra eles de homework e só corrijo em aula. Senão é muito tempo, se tu for fazer todos os exercícios não dá

Lucas: Sim, eu já dei, eu comecei a dar

Adam: É muita coisa, mas eu adoro este livro

Lucas:Tá. Valeu ${ }^{16}$

In the beginning of the segment, participants address the fact that there is always music in the teachers' room: either there is a music video playing on YouTube, someone playing the guitar on the lawn outside or singing in the room ("You know, guys, it's a lot of singing"). Then, Lucas gazes at Adam, and asks him if he should do all the reviews ${ }^{17}$ in the American English File book ${ }^{18}$. Adam, responding to Adam's question as addressed at him, asks a follow-up question ("which reviews?"). Lucas, then, explains that he is talking about the reviews in the American English File, one of the few books adopted in the program. Adam, subsequently, narrates what he usually does with the reviews in his own classes, which is assigning them as homework, since the course book has too much material to cover in class. Lucas responds that this is what he

\footnotetext{
${ }^{14}$ Henceforth I will present the original transcription in Portuguese in the text and its translation in footnotes. All translations here are my responsibility. When the text in the body is already in English and no translation is provided, it means that the original was already in English. For the sake of simplicity, I will quote the translation in English in my discussion.

${ }^{15}$ Adam: You know, guys, it's a lot of singing.

Lucas: Hey, should we do all these reviews with the students?

Adam: Which reviews?

Lucas: Those in the American English File.

Adam: Look, here's what I do: I give them the review as homework and just check it in class. If you are going to do all the reviews, it takes too long.

Lucas: Yes, I'm doing it, I have just started doing it.

Adam: It's a lot of stuff, but I love this book.

Lucas: All right. Good one.

${ }^{16}$ My translation and, thus, responsibility.

${ }^{17}$ American English File 1, second edition. The book is divided in units. Each unit has three lessons and one review lesson, which closes the unit sequence.

${ }^{18}$ As Auer (2015) explains, gaze is often used for addressee selection in non-dyadic arrangements.
} 
REVISTA X, Curitiba, volume 14, n.6,p. 107-127, 2019.

had been doing, and closes the sequence by thanking Adam. In this segment, we have a novice teacher (Lucas) checking with a more experienced peer (Adam) if his procedure regarding course book use was aligned with CoPs expectations, or at least with the views of a more experienced peer. Adam backchannels his advice by narrating what he usually does in his own classes, rather than actually phrasing straightforwardly as advice. Lucas closes the segment off by thanking Adam for his help ("Good one").

This segment makes it explicit the role of the more experienced peer - the student teacher who has had more experience teaching and who has taught for the longest is the one sought out for help. He understands that and immediately starts trying to understand the situation in order to give advice. Rather than adopting a prescriptive or lecture key, he gives his advice by referring to what he does in his own classes. In other words, he uses past experiences to illuminate a present moment issue, and does so in a narrative key. The role of the more experienced peers is also central in the next segment. I will contextualize the situation and, then, present it.

In the teachers' room, Adam, Adri and Josiare talking and doing their work (planning classes, grading papers) - the former two sitting at the desktops; the latter sitting in the couch. They are eating - tangerines, Oreo and crackers, as the school cafeteria has been closed for a while now and they have to improvise lunch. Adam asks people if they want to be volunteers to test the warm-up task he is designing; people nod positively.However, while Adam is about to begin explaining the task, Adri asks for help.

\section{Excerpt 2: "Do you have any idea for a warm-up?"19}

\footnotetext{
${ }^{19}$ Adri: People, do you have any idea for a warm up? Like, for writing. Adam: Writing? Is it a writing class? Is it basic level?

Adri: It's B1.

Adam: B1 is easy. Talk about writers, start a conversation about writers.

Adri: But it's academic writing, so every class we do something like this.

Adam: I start from the old assumption that for you to write well you've got to read, right?

Researcher: And write.

Adam: Yes, you've got to have contact with texts. I'd start on the first class...

Adri: No, the course has already started.

Adam: What's your unit about today? What are they writing about?

Adri: They're... We're going to work with those grammar [exercises], before we explore the adjectives, showing [inaudible] Like, we're going to read a text about a polemic issue, like, those that have two really different opinions, you know?

Adam: Ok, you're talking about immigration? I'm preparing class now. I relay like that technique, like... You may even just say "immigration" or you show a video. I even know what video you can show, the first minister of Canada, welcoming Syrians to Canada. It's Justin Trudeau... welcomes... whatever... Syrian immigrants. Let's if it searches [[while writes at the desktop computer]]

[[Background noise. Overlapping voices]]

Adam: This is like 6 minutes long. But, like, he talks to the guys and you see that he has his sleeves rolled up. He says to people, like, welcome, now you're Canadian. Then, he gives them clothes.
} 
REVISTA X, Curitiba, volume 14, n.6,p. 107-127, 2019.

Adri: Gente, vocês têm alguma ideia de um warmup? Tipo de escrever.

Adam: De escrever. É uma aula de escrita? É básico?

Adri: É B1.

Adam: B1 é tranquilo. Fala sobre escritores, puxa um papo sobre escritores.

Adri: Mas é de escrita acadêmica, daí toda aula a gente tem alguma coisa assim.

Adam: Eu parto daquele velho pressuposto que para tu escrever bem tu tem que ler, né?

Antonio: E escrever...

Adam: Sim, tu tem que ter contato com textos. Eu começaria a primeira aula...

Adri: Não, o curso começou já.

Adam: O que que vai ser a tua unidade hoje? Sobre o que eles vão escrever?

Adri: Eles vão... A gente vai trabalhar com aqueles de gramática, antes de explorar os adjetivos, mostrando [inaudível] Tipo, a gente vai pegar um texto sobre um tópico polêmico, tipo, desses que tem duas opiniões bem diferentes, sabe?Tipo...

Adam: Tá, tu vai falar sobre imigração? Tô preparando a aula agora. Eu gosto muito daquela técnica assim... Tu pode até falar immigration ou tu apresenta um vídeo. Já sei qual vídeo tu pode apresentar, do primeiro ministro do Canadá, recebendo os sírios no Canadá. É Justin Trudeau... welcomes... ah, sei lá ... Sirianimmigrants. Vamos ver se busca.

[[Enquanto escreve no computador desktop que fica na sala dos professores]]

[[Barulho de fundo: Vozes sobrepostas]]

Adam: Este aqui de 6 minutos. Não, o de 1:22 já tem.É que o 6:20 é muito. Mas, tipo, ele conversa com a galera, e tu vê que ele tá com a manga arregaçada. Daí ele fala assim pras pessoas, ah, seja bem-vindo, agora tu é um canadense. Daí ele entrega roupa pra $\operatorname{eles}^{20}$.

In this second segment, Adri initiates the request for help to plan a warm-up task for an academic writing class. Differently from the previous segment, she asks a question to everyone in the room rather than selecting a specific addressee. She indexes this openness of interlocutor by looking around and initiating her turn with "people". Although Adam was not selected in the request, he steps up to offer help. Just like in the previous segment, he asks follow-up questions ("Is it a writing class? Is it basic level?")in order to understand how to offer help. Next, Adri explains that it is an intermediate-level class ("B1"21). Then, Adam suggests that Adri starts the class with a talk about writers, which she answers in two different ways: (1) by saying it is an academic class, and (2) by stating that she does it in all classes. One could infer this meant that Adam's suggestion was not exactly helpful. After that, Adam sets the key by offering a general rule ("to write well you've got to read, right?"), stating that "on the first class" he would only to have Adri correct him in the next turn - "No, the course has already started". Adam, then, asks a couple more follow-on questions to help build his help - "What's your unit about today? What are they writing about?".After Adri explains what her class is going to be about, Adam suggests a video featuring Canadian prime minister welcoming Syrian immigrants to Canada; while he explains the video

\footnotetext{
${ }^{20}$ Adri writes down Adam suggestion. The entrance of the coordinator, who needs help for a task, interrupts the talk. After a little while, the room is empty, for people go to the meeting.

${ }^{21}$ In this CoP, the Common European Framework of Reference is widely used as placement, which is explained in https://www.coe.int/en/web/common-european-framework-reference-languages/leveldescriptions (Last Visited: 23 jul. 2019).
} 
REVISTA X, Curitiba, volume 14, n.6,p. 107-127, 2019.

and makes the case that it is a good choice, he opens it on one of the desktop computers. In the meantime, Adri makes notes on a sheet of paper, indexing that she is inclined to accept Adams advice in her class. While all this is taking place, the coordinator enters the room and says that she needs help with a bureaucratic issue, which interrupts the event.

Once again, the figure of the more experienced peers is made relevant. This time not by the participant who asks for help, but by the participant who offers help. Although there were other participants in the room and Adri had not directed the request at any one in particular, Adam volunteered help.

In the synoptic chart below, I summarize the events in which participants asked for and obtained help from their peers; there are nine such events. Afterwards, I will discuss some regularities encountered in the data.

\begin{tabular}{|c|c|c|c|}
\hline Event & Where & Who & Gets help? \\
\hline $\begin{array}{l}\text { 1. Lucas asks } \\
\text { Estevamadvice on how } \\
\text { to work with } \\
\text { pronunciation in class. } \\
\text { They are in a private } \\
\text { meeting, and she gives } \\
\text { him feedback on his } \\
\text { microteaching, when he } \\
\text { introduces the question. } \\
\text { She explains to him } \\
\text { what she usually does in } \\
\text { her own classes. }\end{array}$ & $\begin{array}{l}\text { Estevam's } \\
\text { office }\end{array}$ & Estevam and Lucas & $\begin{array}{l}\text { Yes, she explains to } \\
\text { him how she does it } \\
\text { in her classes. }\end{array}$ \\
\hline $\begin{array}{l}\text { 2. Lucas asks Adam } \\
\text { several questions about } \\
\text { how to use the course } \\
\text { book AMEF, while they } \\
\text { are hanging out in the } \\
\text { teachers' room. While } \\
\text { he likes the course book } \\
\text { and wants to use it, he } \\
\text { also wants to be able to } \\
\text { include tasks with } \\
\text { authentic texts. }\end{array}$ & $\begin{array}{l}\text { Teachers' } \\
\text { room }\end{array}$ & $\begin{array}{l}\text { Adam, Lucas, } \\
\text { AntonioandGrazi }\end{array}$ & $\begin{array}{l}\text { Yes, Adam responds } \\
\text { the questions and } \\
\text { explains how he uses } \\
\text { the book. }\end{array}$ \\
\hline $\begin{array}{l}\text { 3. Lucas wants to know } \\
\text { where he can find the } \\
\text { four stylistic } 22 \\
\text { categories in English.He }\end{array}$ & $\begin{array}{l}\text { Teachers' } \\
\text { room }\end{array}$ & $\begin{array}{l}\text { Adam, Lucas and a } \\
\text { student friends with } \\
\text { them }\end{array}$ & $\begin{array}{l}\text { Yes. He is informed } \\
\text { that the categories } \\
\text { were proposed in } \\
\text { Portuguese and not }\end{array}$ \\
\hline
\end{tabular}

${ }^{22}$ Guedes (1997), a reference to the teaching writing in Portuguese widely used at the university. The author refers to four stylistic qualities in a text: thematic unit, concreteness, objectiveness, and questioning (unidade temática, concretude, objetividade e questionamento). 
REVISTA X, Curitiba, volume 14, n.6,p. 107-127, 2019.

\begin{tabular}{|c|c|c|c|c|}
\hline & $\begin{array}{l}\text { asks this to everyone } \\
\text { who is in the room and } \\
\text { explains that he finds it } \\
\text { hard to find criteria that } \\
\text { makes sense to teach } \\
\text { and evaluate writing. } \\
\text { He learned about these } \\
\text { categories in his writing } \\
\text { classes in Portuguese in } \\
\text { college. }\end{array}$ & & & in English. \\
\hline 4. & $\begin{array}{l}\text { Adam asks his peers a } \\
\text { suggestion ofa scene in } \\
\text { a sitcom that he can use } \\
\text { to work with } \\
\text { cooking.He thought of } \\
\text { using a scene with } \\
\text { speed dating from the } \\
\text { movie "The } 40 \text { Year- } \\
\text { Old Virgin", but there } \\
\text { was too much cursing. } \\
\text { The peers engage in } \\
\text { offering suggestions } \\
\text { Adam could use in } \\
\text { class. However, Adam } \\
\text { gives up and says that } \\
\text { he will look for it later. }\end{array}$ & $\begin{array}{l}\text { Teachers' } \\
\text { room }\end{array}$ & $\begin{array}{l}\text { Adam, Lucas and a } \\
\text { Letras student friends } \\
\text { with them }\end{array}$ & $\begin{array}{l}\text { Yes. His peers } \\
\text { recommend two } \\
\text { different scenes, } \\
\text { though he does not } \\
\text { go with any of them. }\end{array}$ \\
\hline & $\begin{array}{l}\text { Lucas asks to shadow } \\
\text { someone who is } \\
\text { teaching a class with the } \\
\text { course book Jetstream } \\
\text { before he begins using } \\
\text { it in a course. In the } \\
\text { room, no one is using } \\
\text { said course book. Then, } \\
\text { Grazi remembers that } \\
\text { one of their peers, who } \\
\text { is not present in the } \\
\text { discussion, uses } \\
\text { Jetstream and really } \\
\text { likes it, which, } \\
\text { according to her, makes } \\
\text { the peer a good } \\
\text { candidate to learn about } \\
\text { the book from. Lucas } \\
\text { says he will contact the } \\
\text { peer. }\end{array}$ & $\begin{array}{l}\text { Teachers' } \\
\text { room }\end{array}$ & $\begin{array}{l}\text { Lucas, Grazi and } \\
\text { Josiana }\end{array}$ & $\begin{array}{l}\text { Yes. The peers } \\
\text { recommend another } \\
\text { student teacher who } \\
\text { has been working } \\
\text { with the book for a } \\
\text { while and seems to } \\
\text { like it. }\end{array}$ \\
\hline & $\begin{array}{l}\text { Mariana asks Nadia for } \\
\text { a short report on her } \\
\text { class about water use } \\
\text { using the course book } \\
\text { Jetstream.Nadia } \\
\text { engages in a thorough } \\
\text { narrative of how she } \\
\text { taught said class, }\end{array}$ & $\begin{array}{l}\text { Teachers' } \\
\text { room }\end{array}$ & $\begin{array}{l}\text { Mariana, Nadia and } \\
\text { Grazi }\end{array}$ & $\begin{array}{l}\text { Yes, Mari gives } \\
\text { Nadia a full narrative } \\
\text { of how the class was } \\
\text { - the good and bad } \\
\text { aspects. Then, she } \\
\text { gives advice to } \\
\text { enhance what is }\end{array}$ \\
\hline
\end{tabular}


REVISTA X, Curitiba, volume 14, n.6,p. 107-127, 2019.

\begin{tabular}{|c|c|c|c|}
\hline $\begin{array}{l}\text { including what worked, } \\
\text { what did not work and } \\
\text { what she would have } \\
\text { done differently. } \\
\text { Finally, she gives some } \\
\text { advice on how she } \\
\text { would teach this class } \\
\text { again if she had to. }\end{array}$ & & & $\begin{array}{l}\text { potentially good and } \\
\text { mitigate what is } \\
\text { potentially bad. }\end{array}$ \\
\hline $\begin{array}{l}\text { 7. Adriana asks her peers } \\
\text { for help with her } \\
\text { writing class. She is } \\
\text { having a hard time } \\
\text { finding interesting } \\
\text { icebreakers for the } \\
\text { writing class }^{23} \text {. }\end{array}$ & $\begin{array}{l}\text { Teachers' } \\
\text { room }\end{array}$ & Adriana and Adam & $\begin{array}{l}\text { Yes, Adam suggests } \\
\text { a video and she } \\
\text { writes down his } \\
\text { suggestion. }\end{array}$ \\
\hline $\begin{array}{l}\text { 8. Mirian asks for help } \\
\text { with vocabulary for her } \\
\text { class. She is designing a } \\
\text { class aimed at teaching } \\
\text { action verbs in the past. } \\
\text { So she is listing a lot of } \\
\text { different verbs related } \\
\text { to activities children } \\
\text { usually do (skipping } \\
\text { rope, playing hide and } \\
\text { seek, etc.), for this is the } \\
\text { context she will use in } \\
\text { class. While she is at } \\
\text { the computer, she keeps } \\
\text { asking everyone else in } \\
\text { the room for the } \\
\text { translations of the } \\
\text { expression she wants to } \\
\text { use in class. }\end{array}$ & $\begin{array}{l}\text { Teachers' } \\
\text { room }\end{array}$ & $\begin{array}{l}\text { Adam, Pedro and } \\
\text { Grazi }\end{array}$ & $\begin{array}{l}\text { Yes. Pedro translates } \\
\text { the words as she } \\
\text { needs them. }\end{array}$ \\
\hline $\begin{array}{l}\text { 9. Mariana asks for advice } \\
\text { on how to teach relative } \\
\text { clauses. According to } \\
\text { her, she has run out of } \\
\text { ideas. All the peers in } \\
\text { the room pitch in } \\
\text { different suggestions for } \\
\text { her. }\end{array}$ & $\begin{array}{l}\text { Teachers' } \\
\text { room }\end{array}$ & Mariana and Antonia & $\begin{array}{l}\text { Yes, many peers give } \\
\text { suggestions. }\end{array}$ \\
\hline
\end{tabular}

Table 2: Requesting help: synoptic chart

The first thing that calls attention in the collection above is the fact that most requests for help happen in the teachers' room - eight out of nine of the events happen in the teachers' room and have student teachers as focal participants. Participants had pedagogical meetings every Friday and feedback sessions with the coordinator every

\footnotetext{
${ }^{23}$ It corresponds to excerpt 2.
} 
REVISTA X, Curitiba, volume 14, n.6,p. 107-127, 2019.

now and then; they also had lesson planning sessions with the ETAs every once in a while. Still, in most cases they sought help with peers in the teachers' room.

Additionally, there is a thematic connection among the events. In the collection presented above, participants align to the resolution of problems related to their work in the program and they cannot themselves resolve by themselves. The events revolve around the following themes: teaching a skill; using the course book (twice); finding a theoretical reference; finding a text to use in class; discussing vocabulary items for class; teaching a grammar topic. All of these themes are connected with one or another aspect of EAL teaching.

Furthermore, it is possible to see the role of the more experienced peers in these student teachers' development. For instance, in event 1, Lucas asks Estevam, his coordinator, for help with something he does not know how to do - teach pronunciation in class. The coordinator is the most experienced member in the community. In events 2 and 3, Lucas selects Adam to help him. In both segments whose transcriptions have been presented earlier, the more experienced peer who offers help is Adam - in the first he does it because he is selected while in the second one he volunteers help.

Another interesting aspect of this practice is that all the interactional events that comprise it take place in Portuguese. This is not the case with a great deal of the data generated for this investigation. Lastly, it is important to notice that offering help is the preferred response; this way, if the participant requests help, he will most likely receive it.

I will close this section by quoting a segment from an interview and contextualizing it:

I was always looking for Maria Julia and Clarissa, they were always helping me. Maria is still helping me with everything. It was amazing! I was always learning from them because, you know, the coordinators were always there to help us. I mean especially through Facebook, they were always there, but, then, seeing them was kinda hard, you know, they're busy.

In the interviews, participants mentioned the importance of having people around them to help when push came to shove. This is clear in the passage above, extracted from Antonio's interview, in which he acknowledges the help he received from his peers and coordinators as an important source of learning. Adding some context, Antonio is a former student teacher of the program (from the second cohort) who still hangs around the teachers' room and many of the pedagogical meetings, while 
REVISTA X, Curitiba, volume 14, n.6,p. 107-127, 2019.

Maria Julia and Clarissa were his old-timers (student teachers in the first cohort). All interviewees concur that help was an essential component to their professional development, one without which their experience would have been poorer. Therefore, participants see the opportunities of obtaining help from more experienced peer as an avenue for professional development, as a way to improve their teaching, as a way to learn how to teach. In this sense, the interactional evidence suggests that - with the help of their peers - participants are able to do things they probably would not alone, in alignment with CoP's values. Further, as they look back in time, they recognize in their narratives that those moments conducted to learning.

In the final section of this text, I will discuss some of the implications of the present data for the field of professional development and provide some recommendations based on the analysis presented here.

\section{DISCUSSION}

The data presented here offers evidence that professional development can emerge from situations that have not been planned, or would not be recognized as professional development under a more traditional light, but which have been claimed by important teacher educators and teacher education researchers as a necessary outlook on teacher development. In other words, a good deal of our professional learning happens in everyday practice and through real professional challenges experienced in the profession and with the help of more experienced peers. This converges with the views proposed by Nóvoa $(1992 ; 2007)$ of placing teacher development "within" the profession.

In a $\mathrm{CoP}$ approach, learning is viewed as social production of identities (WENGER, 1998; 2010). According to the author, "learning is not just acquiring skills and information; it is becoming a certain person-a knower in a context where what it means to know is negotiated with respect to the regime of competence of a community" (WENGER, 2010, p. 2). Learning is "a social becoming" (p. 3). It is interesting to follow how the data presents evidence of that in the two dimensions discussed in the literatures review: participation and reification. In the interactions' segments presented, participants ask for help and get it from a more experienced peer, who is likely to be able to help them realign their performance with what is expected from the community; this is participation. In the interview segment presented earlier, we can spot someone who had had its course in the community (he is a former participant) explaining how 
help from his more experienced peers helped him navigate the community, looking back into the past; this is reification. Newbie becomes experienced member. This is probably why the more experienced peer is so central in situated approaches to learning, as in the case in Lave and Wenger (1991) and Wenger (1998). This also seems to appear in the data presented here ${ }^{24}$. Thus, for this kind of interaction to be possible, it is essential that participants have space to interact - as it is the case with the teachers' room in this CoP, but could consist of other settings (physical or virtual) in other CoPs. In Wenger (1998), the more experienced peers are considered central to the success of a community, for they help newcomer not only by teaching them, but by being examples of "what is possible, expected and desired" (p. 156), which may help newcomers find their own trajectories inside the community and construct their repertories to participate more fully in the CoP. This seems to be the case here in a number of ways. First, in both excerpts presented here, a more experienced peer either is selected in the request for help or self-selects to offer help when someone requests it for everyone/anyone in the room. This aspect also converges with previous literature on language teacher development in CoPs. Adam shows his peers what is possible, expected and desirable in the CoP based on his own experiences. The importance of assistance from peers has also appeared in the work of other researchers working specifically with the development of language teachers. Merril (2016), for instance, argued that student teachers could benefit from the relationship of a more experienced peer - "graduate advisor, their department's pedagogy specialist, their course coordinator, a teaching mentor, or another mentor" (p. 185) -, especially in the context of group settings, which "could provide opportunities for peer mentoring between the members of the group" ( $p$. 185). Costa (2013) pointed out that teacher development events are usually arranged so that the more experienced peer is in charge of teaching others based on his/her own lived experiences. The data presented here converges with both.

Finally, I would like to close this text by presenting some recommendation that stem from the data analysis presented here. CoPs are essential for professional development because they provide participants with the opportunity for an array of interactions that will permit them to constantly realign self with expected competence(Wenger, 2010). Additionally, stimulating the contact of new bies with

\footnotetext{
${ }^{24}$ I am purposefully leaving aside the obvious relation of this with the concept of Zone of Proximal Development in Vygotsky (1978) for a future endeavor. Nevertheless, it constitutes a limitation of the present study.
} 
REVISTA X, Curitiba, volume 14, n.6,p.107-127, 2019.

more experienced peers (not necessarily the teacher educator or the boss) seems like a good idea, for it might push teachers in the direction of the kinds of interactions that seem to culminate in development.

\section{REFERENCES}

AUER, P. Gaze, addressee selection and turn-taking in three-party interaction. In: BRONE, G.; OBEN, B. (Eds.) Eye-tracking in Interaction: Studies on the role of eye gaze in dialogue. Amsterdam: John Benjamins Publishing Company, 2015.

AVALOS, B. Teacher professional development in Teaching and Teacher Education over ten years. Teaching and Teacher Education, v. 27, n. 1, p. 10-20. Janeiro 2011. Disponível em: https://doi.org/10.1016/j.tate.2010.08.007 Acesso em: 23 jul. 2019.

BAKHTIN, M. The dialogic imagination : four essays. Austin, TX: University of Texas Press, 1981.

COSTA, E. V. Práticas de Formação de professores de Português Língua Adicional em um Instituto Cultural Brasileiro no exterior. Porto Alegre. [Dissertação de Mestrado]. Universidade Federal do Rio Grande do Sul, PPGLET, 2013.

ERICKSON, F. Qualitative Methods. In: R Linn, R. F.; ERICKSON, F. Qualitative Methods, Quantitative Methods. London, UK: Macmillan, p. 0-77, 1990.

GARCEZ, P. M.; SALIMEN, P. G. Pedir e oferecer ajuda para "fazer aprender" em atividades pedagógicas de encenação na fala-em-interação de sala de aula de inglês como língua adicional. In: BARCELOS, A. M. (Org.). Linguística Aplicada: reflexões sobre ensino eaprendizagem de língua materna e língua estrangeira. Campinas: Pontes, p. 97-117, 2011.

GASNER, T. An ambitious vision of professional development for teachers. NASP Bulletin, v. 84, n. 618, p. 06-12.Outubro 2000. Disponível em: https://doi.org/10.1177 /019263650008461801 Acesso em: 23 jul. 2019.

GOODWIN, C.; DURANTI, A. Rethinking context: an introduction. In: DURANTI, A.; GOODWIN, C. (Eds.), Rethinking Context: Language as an interactive phenomenon. Cambridge: Cambridge University Press, p. 1-42, 1992.

GUMPERZ, J. Interactional sociolinguistics: A personal perspective. In: SCHIFFRIN, D; TANNEN, D.; HAMILTON, H. The Handbook of Discourse Analysis. Hoboken, NJ: Blackwell Publishers, p. 215-228, 2005. Disponível em: https://doi.org/10.1002 19780470753460.ch12 Acesso em: 23 jul. 2019.

HEATH, S. B. What no bedtime story means: Narrative skills at home and school. Language in Society, v. 11, n. 1, p. 49-76. Abril 1982. Disponível em: https://doi.org/ 10.1017/S0047404500009039 Acesso em: 23 jul. 2019.

HEATH, S. B.; STREET, B. On ethnography: approaches to language and literacy 
REVISTA X, Curitiba, volume 14, n.6,p. 107-127, 2019.

research. New York: Teachers College Press, 2008.

LAVE, J.; WENGER, E. Situated learning: legitimate peripheral participation. Cambridge [England]; New York: Cambridge University Press, 1991.

LEVINSON, S. C. Activity types and language. In: DREW, P.; HERITAGE, J. (Eds.). Talk at work: Interaction in institutional settings. Cambridge University Press, p. 66-100, 1992.

LÓPEZ MONGE, C.; GÓMEZ HERNÁNDEZ, P. (Eds.) Innovando la docencia desde la formación del profesorado. Madrid: Editorial Síntesis, 2018.

MASON, J. Qualitative researching. Second edition. London; Thousand Oaks, Calif.: Sage Publications, 2002.

MERRILL, M. Communities of Foreign Language Teachers as a Source of Professional Development. [Tese de doutorado]. University of Wisconsin Madison, SLA PhD, 2016.

NÓVOA, A. Formação de Professores e Profissão Docente. In: NÓVOA, A. Os Professores e a sua formação. Lisboa: Don Quixote, 1995.

NÓVOA, A. (2007). O regresso dos professores. Conference on Teacher Professional Development for the Quality and Equity of Lifelong Learning", 2007. Retrieved from http://repositorio.ul.pt/bitstream/10451/687/1/21238_rp_antonio_novoa.pdf Acesso em: 03 abril 2019.

OECD. Teachers Matter. OECD Publishing, 2006. Available at: https://doi.org /10.1787/9789264022157-ja Acesso em: 23 jul. 2019.

SCHÖN, D. A. Educating the reflective practitioner: toward a new design for teaching and learning in the professions. First edition. San Francisco: Jossey-Bass, 1987.

TANNEN, D..What s in a Frame? for Underlying Expectations. In: Freedle, R. (Ed.), New Direction in Discourse Processing. Norwood, NJ: Ablex, p. 137-181, 1979.

VILLEGAS-REIMERS, E. (2003). Teacher professional development : an international review of the literature. Paris: International Institute for Educational Planning, 2009.

VYGOTSKIĬ, L. S. Mind in society: the development of higher psychological processes. Cambridge: Harvard University Press, 1978.

WENGER, E. Communities of practice: learning, meaning, and identity. Cambridge, U.K.; New York, N.Y.: Cambridge University Press, 1998. Retrieved from https://search.library.wisc.edu/catalog/999849504402121 Acesso em: 23 jul. 2019.

WENGER, E. Communities of practice and social learning systems : the career of a concept A social systems view on learning: communities of practice as social learning systems. In: BLACKMORE, C. (Ed.) Social Learning Systems and Communities of Practice. London: Springer, p. 225-246, 2010. Available at: https://doi.org/doi: 
REVISTA X, Curitiba, volume 14, n.6,p. 107-127, 2019.

10.1177/135050840072002 Acesso em: 23 jul. 2019.

YOUNG, R. Discursive practice in language learning and teaching. Chichester; Malden, Mass.: Wiley-Blackwell, 2009. 